Original Research Paper

\title{
Effect of Gamma Radiation on Oil Quality of Dried Mint Leaves
}

\author{
${ }^{1}$ Abd El-Rahman Abd El-Raouf Ahmed*, ${ }^{2}$ Gamal Kamal Arafa, \\ ${ }^{3}$ Helmy El-Sayed Hassan and ${ }^{4}$ Hend Nabil Mohamed \\ ${ }^{1,2}$ Agricultural Engineering Research Institute, Agricultural Research Center, Egypt \\ ${ }^{3}$ Laser Application in Agricultural, National Institute of Laser Enhanced Sciences, Cairo University, Egypt \\ ${ }^{4}$ Agricultural Marketing, Agricultural Economic Research Institute, Agricultural Research Center, Egypt
}

Article history

Received: 11-02-2020

Revised: 26-03-2020

Accepted: 23-05-2020

Corresponding Author:

Abd El-Rahman Abd El-Raouf

Ahmed

Agricultural Engineering

Research Institute, Agricultural

Research Center, Egypt

Email: abdo_aaaa2000@yahoo.com

\section{Introduction}

Some herbs or crops are consumed in their fresh state and may deteriorate within a few days after harvest. One way to preserve these plant products is to dry them in either by traditional sun/shade drying or microwave drying/oven drying. The area of the mint farm in Egypt is about 4312 Feddan ( 1 hectare $=2.4$ Feddan $)$ during the winter and summer seasons, with a rate of $6.2 \%$ of the total area of medicinal and aromatic plants, amounting to 69154 Feddan in 2018. ASEAS (2018). In terms of foreign trade, the value of Egyptian mint oil reached about an amount of exports amounting to about Properties and Quality
Abstract: The green mint crop is considered a medicinal and aromatic plant grown in most of Egypt's governors and it has multiple uses, whether it is used fresh or dried or mint oil is extracted from it and mint is also known as its medicinal importance as research has proven that it has many health benefits. This research was conducted to study the effect of gamma irradiation on the oil quality assessment of dried mint leaves. Dry mint leaves were treated by using doses of gamma radiation, $0.0,5,10,15$ and 20 kGy. The color properties as Chlorophyll a, Chlorophyll b and total phenols, total flavonoids and ascorbic acid of aqueous extract of mint leaves have been evaluated. The highest content of chlorophyll $a$, chlorophyll $b$, total chlorophyll and content of carotenoids in the dried mint leaves was observed in irradiated samples with $20 \mathrm{kGy}$. While, the highest content was in the irradiated sample with $5 \mathrm{kGy}$. The data demonstrated the irradiated dried mint leaves at 5, 10, $15 \mathrm{KGy}$ had lower phenolic, flavonoids, total antioxidant and ascorbic acid compounds than nonirradiated control in the mint extract. While, irradiated mint at $20 \mathrm{kGy}$ had higher phenolic compounds. It was found significant differences in the content of chlorophyll (a), chlorophyll (b), phenol, flavonoids, antioxidants, content. By using of irradiation with gamma rays of $20 \mathrm{kGy}$, the most influencing was the higher content of chlorophyll (a) and chlorophyll (b). While the use of the level of irradiation with gamma rays of $15 \mathrm{kGy}$ had a greater impact on the high content of carotene, phenol, flavonoids. Also, the use of irradiation at $10 \mathrm{kGy}$ levels had the best effect on the high content of antioxidant and ascorbic acid. This study indicated the Gamma irradiation of dried peppermint leaves may lead to improved quality of oil.

Keywords: Mentha piperita L, Gamma, Drying, Physical, Chemical

291 tons in 2018 and the rate of export growth increased with a growth rate in the amount of exports of about 87\% between 2014-2018 (UNMS, 2018).

Eliana et al. (2016) evaluated the effects of gamma irradiation on cytotoxicity and phenolic compounds of Thymus vulgaris $L$. and Menta piperita L., used in traditional medicine. Thirteen and fourteen phenolic compounds were detected in T. vulgaris and Mentha piperita, respectively, none of which was affected by the irradiation dose used (10 kGy).

Amnah and Amal (2013) conducted to study the effect of gamma irradiation on the antioxidant activity, 
quality assessment of microbial and sensory for fresh mint leaves. A high antioxidant activity when radioactive transactions gave a significant increase in the content of total phenols and total flavonoids compared to nonirradiated samples. Eric (2013) analyzed the effect of the drying methods on the nutritional characteristics of the spicy basil leave. Microwave-drying and oven drying were the methods that produced the best results for preserving most nutrients compared to the fresh herb, whereas ambient-air-drying, hot-air-drying and sun-drying brought about substantial losses in basil leave nutritional values.

Gavahian et al. (2015) used that Steam Distillation (SD) for extraction of essential oils from Mentha piperita L. (peppermint) and the results were compared with those of the Hydro Distillation (HD). The results showed that although extraction with HD started sooner, both methods had the extraction time of about $1 \mathrm{~h}$.

Ghanooni et al. (2015) mentioned that the Mentha piperita $L$. Essential oils have different a bacterial activity. They investigated the effect of $\gamma$-irradiation on the bacterial activities of Mentha piperita L. Eessential oils in vitro and in vivo systems. The aerial parts of peppermint were irradiated in a cobalt 60 source with 0 , 10 and $25 \mathrm{kGy}$ absorbed doses. The oil was effective in reducing CFU caused by sepsis-induced CLP operation.

Generally, these processes may cause negative attribute to the final food product, Phenolic compounds possess a wide spectrum of biological effects including antioxidant and free radical scavenging properties. Phenolic is classified into two groups such as polyphenols and simple phenols according to (Marinova et al., 2005). Drying is the most common and effective method that increases the shelf life of spicy herbs by inhibiting the growth of microorganisms and preventing the onset of some biochemical reactions that may alter the organoleptic and nutritional characteristics of the dried leaf. However, drying must be performed carefully in order to preserve the aroma, appearance and nutritional characteristics of the raw herbs as much as possible (Crivelli et al., 2002). Yousif et al. (1999) mentioned that during the long hours of drying heat was conducted from the surface to the interior of the leaves and the rate of evaporation of water on the surface of the leaves was faster than the rate of diffusion to the surface. However, all dried leaves achieved moisture content less than $20 \%$ wt.

Exposing food material to radiation has great advantages in contrast to the conventional methods of preservation such as cold storage, fumigation, salting and drying as it does not lead to loss of flavor, odor, texture or quality. In addition, irradiation is a direct, simple and efficient one-time process. Irradiation treatment combined with proper refrigeration for storage can prolong the shelf-life of these food items without affecting the flavor and texture (Shurong et al., 2005).

Preserving food through radiation is considered a promising method to enhance the safety of the microbial quality of the food as it prolongs the period of validity.
Based on that, the radiation is considered a safe method of preserving food from microbial deterioration and consequently prolonging its marketing period (Haruvy and Deschenes, 2003). Boiling water extracted more polyphenols from dried plant materials than cool water, which means the heat of boiling water was the factor that led to higher total phenols being extracted from dried plant materials (Toor and Savage, 2004). Fatemi et al. (2010) showed that the $\gamma$-irradiation can be an effective way to treat problems in food supply pollution. The antibacterial activities of irradiated peppermint oil at two radiation doses of $10 \mathrm{kGy}$ (the maximum permissible dose of radiation in food) and $25 \mathrm{kGy}$ (sterile dose that all biological agents contaminating peppermint die) were studied to consider whether the $\gamma$-irradiation preserved the in vivo and in vitro antibacterial activities. Chlorophylls and carotenoids are frequent organic food components because they are naturally present in plants, giving them specific coloration. In vivo, these pigments play key roles in photosynthesis (Schoefs, 2002).

Among these tea pigments, pheophytins $a$ and $b$ were abundant, followed by chlorophylls $a$ and $b$ and carotenoids such as $\beta$-carotene and lutein in lower concentrations. All these pigments exhibited significant antioxidant activities against hydroperoxide generation, in the order chlorophyll $a>$ lutein > pheophytin $a>$ chlorophyll $b>\beta$-carotene > pheophytin $b$ (Loranty et al., 2010). In particular, gamma irradiation was approved for disinfection and microbial control in various food products and supplements by the Food and Drug Administration (FDA), being a procedure technically and economically viable and physically safe with a powerful antimicrobial effect (Mizani et al., 2009). They reported that sun drying of green leafy vegetables caused a significant increase in TPC, reducing property and free radical scavenging activity, even though there was a significant decrease in vitamin C content according to (Oboh et al., 2009).

The aims of the current study were: (a) Drying of mint leaves using sun-drying method., (b) Select suitable dose of gamma radiation to irradiate dried mint leaves., (c) Studying some physical and chemical properties of extracting oil before and after irradiation and (d) Examine the influence of gamma radiations on oil mint quality.

\section{Materials and Methods}

\section{Sample Preparation}

The samples of fresh mint were purchased from a local market in Giza region, Egypt in July 2018. The leaves were carefully cleaned manually to remove dirt and damaged ones and were removed from the stalks. Then, the mint leaves were washed subjected to sun drying to achieve a percentage moisture content of $<20 \%$ at four days to dry in the Sun. Dried Mint leaves (moisture content $<20 \%$ ), were sealed in low density polyethylene bags and stored at $4 \pm 1^{\circ} \mathrm{C}$ until exposed to gamma radiation. 


\section{Moisture Content}

The moisture content of the Mint leaves was determined by the method of the difference between weights before and after exposing to hot air oven at $70^{\circ} \mathrm{C}$ for $72 \mathrm{~h}$ is considered as moisture. The percentages of moisture were calculated as follows (Anonymous, 1990):

$$
\text { Moisture content, } \%=W 1-W 2 / W 1 * 100
$$

Where:

$W 1=$ Weight of the sample before drying, $\mathrm{g}$

$W 2$ = Weight of sample after drying, $\mathrm{g}$

\section{Gamma Irradiation Treatments}

Dried Mint leaves divided into 5 groups and treated with ${ }^{60} \mathrm{Co}$ (Cobalt 60) gamma rays, at the National Center for Radiation Research and Technology (NCRRT), Egypt. Dried Mint leaves were exposed to different doses of $\gamma$ - rays; 0 (control), 5, 10, 15 and 20 $(G y)$. The control and irradiated samples were stored in plastic containers at room temperature $\left(28-30^{\circ} \mathrm{C}\right)$.

\section{Preparing of Dry Mint Extract Samples}

Dried mint leaves which exposed to radiation in various doses were extracted by mixing them with distill water and stirring and turning for $15 \mathrm{~min}$, then separated in Centrifugal Concentrators for $10 \mathrm{~min}(1000 \times \mathrm{g})$. After filtering and extraction, a $110 \mathrm{~mL}$ were obtained and three replicates have been made after each test analysis (Pellegrini et al., 2003).

\section{Determination of Chlorophyll $a$, Chlorophyll $b$ and Carotenoids}

The extraction process was done in triplicate. The solution was analyzed for Chlorophyll $a$ (Ch $a)$, Chlorophyll $b(\mathrm{Ch} b)$ and carotenoid content by a spectrophotometer JENWAY 6300 at various wavelengths 470,645 and $662 \mathrm{~nm}$ is using a glass cuvette. The equations used for the quantification are given in Table 1. Results were expressed as $\mathrm{mg} \mathrm{g}^{-1}$ of plant material.

The equations for calculation of chlorophyll $a$, chlorophyll $b$ and the total carotenoid content (Sumanta et al., 2014).

\begin{tabular}{ll}
\hline Parameter, units & Equations* \\
\hline Chlorophyll $a$, mg ml-1 & $1 C_{c h a}=12.25 \mathrm{~A}_{662}-279 \mathrm{~A}_{645}$ \\
Chlorophyll $b$, mg ml-1 & $C_{c h b}=24.5 \mathrm{~A}_{645}-5.1 \mathrm{~A}_{662}$ \\
Total chlorophyll, mg ml-1 & $1 C_{c h t}=C_{c h o}+C_{c h b}$ \\
Ratio between chlorophyll $a$ and $b=\frac{C_{c h a}}{C_{c h b}}$ \\
Total carotenoids, mg ml-1 & $C_{c a}=\frac{C_{c h o}=1000 \mathrm{~A}_{470}-1.82 C_{c h a}-85.02 C_{c h b}}{198}$ \\
\hline
\end{tabular}

*In column Equations following abbreviations are used:

$C_{C h a}=$ Concentration of chlorophyll $a$ in extract

$C_{C h b}=$ Concentration of chlorophyll $b$ in the extract

$C_{C h t}=$ Concentration of total chlorophyll in extract

$C_{C c a}=$ Concentration of carotenoids in extract

$A 662=$ Absorbance of the extract at wavelength $662 \mathrm{~nm}$

A645 = Absorbance of the extract at wavelength $645 \mathrm{~nm}$

$\mathrm{A} 470=$ Absorbance of the extract at wavelength $470 \mathrm{~nm}$

\section{Total Antioxidant Assay}

The antioxidant content has been estimated as an equivalent to Quercetin according to Meda et al. (2005).

\section{Phenolic Analysis}

The extracts obtained above were analyzed using an HPLC chromatograph (HewlettePackard 1100, Agilent Technologies, Santa Clara, CA, US) with a double online detection using a Diode Array Detector (DAD) with 280, 330 and $370 \mathrm{~nm}$ as preference wavelengths and a Mass Spectrometer (MS) equipped with an ESI source and a triple quadrupole-ion trap mass analyzer, which was connected to the HPLC system via the DAD cell outlet (Barros et al., 2013).

Total flavonoids assay: this is accomplished by using the method used by (Meda et al., 2005).

DPPH (2, 2-Diphenyl-1-Picrylhydrazyl) radical scavenging activity assay

Free radical scavenging activity against 2, 2Diphenyl-1-Picrylhydrazyl (DPPH) radical was measured according to the modified method (Oboh, 2005). Ascorbic acid was used as the standard; while the inhibition ratio of DPPH scavenging activity was calculated from the equation:

$$
A A, \%=A c-A c / A c * 100
$$

Where:

$A A=$ Ascorbic acid

$A c=$ Absorbance of control and

As $=$ Absorbance of the test sample.

Statical Analysis

One-way Analysis of Variance was used to analyze the data using the following mathematical model:

$$
Y_{i j}=\mu_{i}+£_{i j}
$$

where, $i=1,2, \ldots . . r$ and $n=1,2, \ldots \ldots, n_{1}$.

\section{Results and Discussion}

\section{Chlorophyll $a$ and Chlorophyll $b$ Contents}

Data of Chlorophyll $a$ and $b$ were illustrated for all the tested mint samples in Table 1 and Fig 1 and 2. Other 
scientists also reported that changes in the colour and the content of chlorophylls were related to the genotype but not to the growing conditions. The highest content of chlorophyll $a$, chlorophyll $b$ and total chlorophyll in the mint leaves was observed $299.79,289.72$ and $589.511 \mathrm{mg} / 100$ oil $\mathrm{g}$ in irradiated sample with $20 \mathrm{kGy}$, respectively. While, the lowest content of chlorophyll $a$, chlorophyll $b$ and total chlorophyll in the mint leaves were observed 178.62, 162.95 and $341.57 \mathrm{mg} / 100$ oil $\mathrm{g}$ in irradiated sample with $5 \mathrm{kGy}$, respectively. These results were found, according to (Bekhradi et al., 2015).

In the tested mint leaves a ratio between chlorophyll $a$ and chlorophyll $b$ ranged from 1.035-1.566, meaning that chlorophyll $a$ is the main form of chlorophyll in the leaves. These results were agreements with (Loranty et al., 2010).

Percentage of decreasing or increasing of chlorophyll $a$ and $b$ differed between all the tested mint samples compared with control samples in Fig. 3 and 4. For chlorophyll a, it was noticed that negative percentage of $39.006,-35.203$ and $-25.634 \%$ for irradiated samples of 5, 10 and $15 \mathrm{kGy}$ while at the irradiated sample with $20 \mathrm{kGy}$ has a positive percentage of $2.370 \%$

For chlorophyll $b$, it was found that negative percentage of-12.842 and $-5.065 \%$ for irradiated samples of 5 and 10 $\mathrm{kGy}$, while at irradiated samples with 15 and $20 \mathrm{kGy}$ has a positive percentage of 1.150 and $54.964 \%$.

Table 1: Chlorophyll a, chlorophyll b and carotenoids of Mint oil at different Gamma radiation doses

\begin{tabular}{|c|c|c|c|c|c|}
\hline \multirow[b]{2}{*}{ Gamma dose, kGy } & \multicolumn{5}{|c|}{ Color properties of Mint oil } \\
\hline & $\begin{array}{l}\text { Chlorophyll a } \\
(\mathrm{mg} / 100 \mathrm{~g}\end{array}$ & $\begin{array}{l}\text { Chlorophyll b } \\
(\mathrm{mg} / 100 \mathrm{~g})\end{array}$ & $\begin{array}{l}\text { Carotenoids } \\
(\mathrm{mg} / 100 \mathrm{~g})\end{array}$ & $\begin{array}{l}\text { Total } \\
\text { chlorophyll }\end{array}$ & $\begin{array}{l}\text { Ratio Chlorophyll } \\
\text { a/Chlorophyll b }\end{array}$ \\
\hline Control & 292.85 & 186.96 & 106.45 & 479.81 & 1.566 \\
\hline 5 & 178.62 & 162.95 & 96.56 & 341.57 & 1.096 \\
\hline 10 & 229.97 & 177.49 & 99.96 & 407.46 & 1.296 \\
\hline 15 & 233.90 & 189.11 & 103.11 & 423.01 & 1.237 \\
\hline 20 & 299.79 & 289.72 & 110.33 & 589.51 & 1.035 \\
\hline
\end{tabular}

Table 2: Chemical properties of Mint oil at different Gamma radiation doses

\begin{tabular}{|c|c|c|c|c|}
\hline \multirow[b]{2}{*}{ Gamma dose, kGy } & \multicolumn{4}{|c|}{ Chemical properties of Mint oil } \\
\hline & Phenols (mg/100g) & Flavonoids (mg/100g) & Total Antioxidant (mg/100g) & Ascorbic acid (mg/100g) \\
\hline Control & 251.94 & 1.84 & 609.75 & 55.47 \\
\hline 5 & 241.61 & 1.14 & 600.87 & 60.77 \\
\hline 10 & 249.02 & 1.52 & 604.20 & 61.15 \\
\hline 15 & 251.30 & 1.73 & 606.87 & 62.48 \\
\hline 20 & 258.82 & 3.28 & 610.62 & 64.47 \\
\hline
\end{tabular}

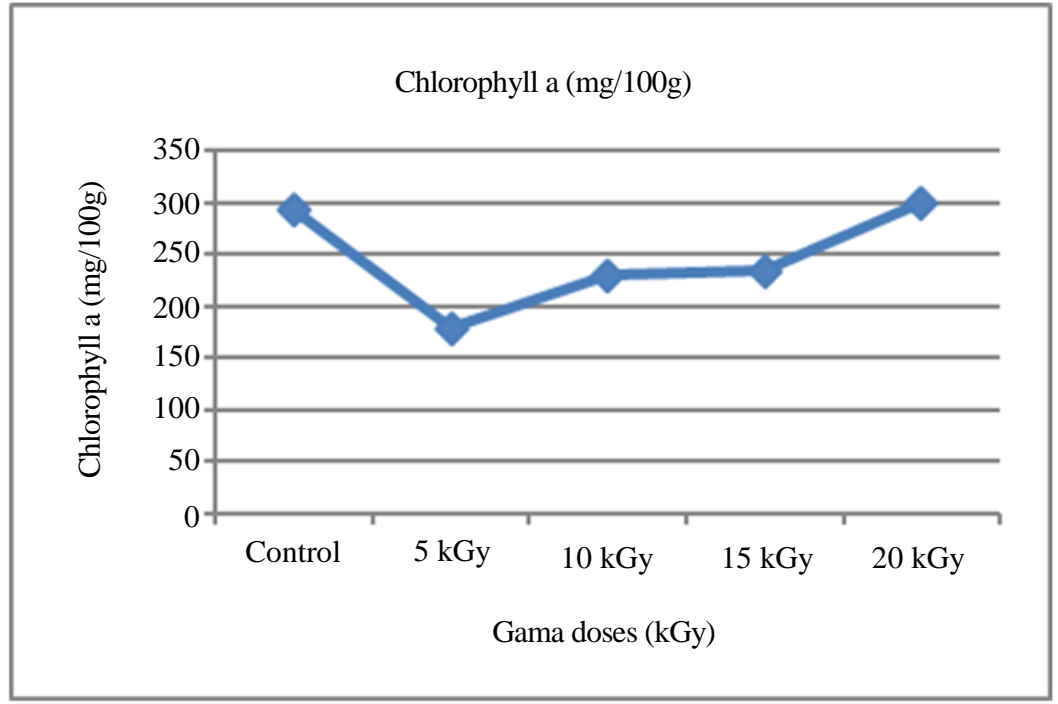

Fig. 1: Effect of gamma radiation doses on Chlorophyll a of Peppermint oil 
Abd El-Rahman Abd El-Raouf Ahmed et al. / American Journal of Agricultural and Biological Sciences 2020, Volume 15: 83.97 DOI: 10.3844/ajabssp.2020.83.97

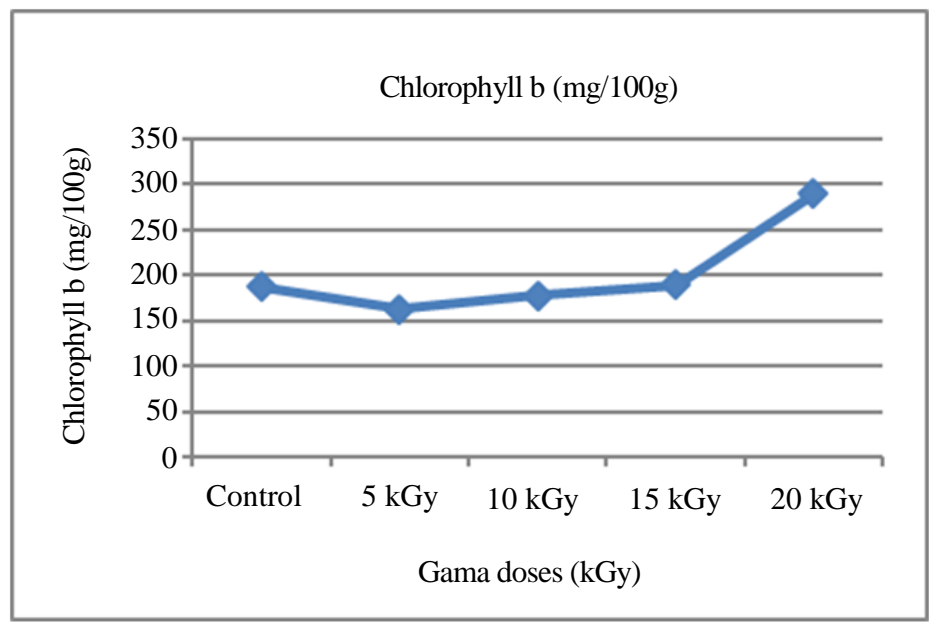

Fig. 2: Effect of gamma radiation doses on Chlorophyll b of Peppermint oil

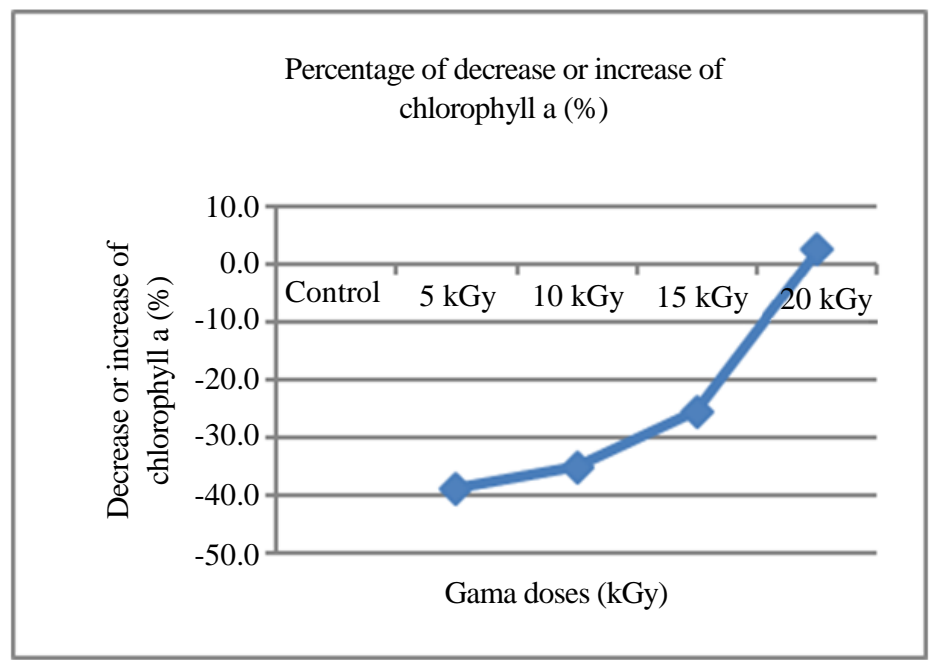

Fig. 3: Decrease or increase of chlorophyll a of peppermint oil at gamma radiation doses

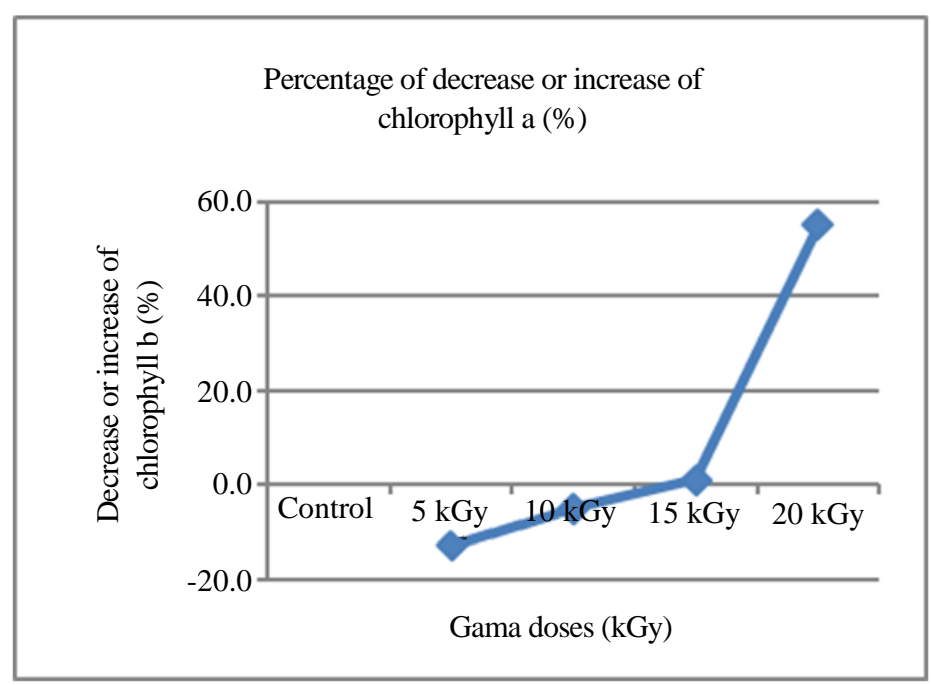

Fig. 4: Decrease or increase of chlorophyll b of peppermint oil at gamma radiation doses 


\section{Carotenoid Content}

The basic pigments of green plants are chlorophylls, always accompanied by carotenoids. The highest content of carotenoids was observed in Mentha spicata leaves, $110.33 \mathrm{mg} 100$ oil g in irradiated sample with $20 \mathrm{kGy}$. While, the lowest content of carotenoids was observed in Mentha spicata 'leaves, $96.56 \mathrm{mg} 100$ oil g in irradiated sample with $5 \mathrm{kGy}$ Table 1 and Fig. 5. Carotenoid content in other herbs like dills is significantly higher $30.3 \mathrm{mg} 100 \mathrm{~g}^{-1}$ (Lisiewska et al., 2004). Percentage of decreasing or increasing of carotenoids differed between all the tested mint samples compared with control samples in Fig. 6. For carotenoids, it was noticed that negative percentage of $-9.291,-6.097$ and $-3.138 \%$ of irradiated samples of 5, 10 and $15 \mathrm{kGy}$, while at the irradiated sample with $20 \mathrm{kGy}$ has a positive percentage of $3.645 \%$.
The Effects of $\gamma$-Irradiation and the Total Phenols and Total Flavonoids

The effects of $\gamma$-irradiation and the total phenols and total flavonoids are shown in Table 2 and Fig. 7 and 8.

The data demonstrated that the irradiated mint at 5,10 , $15 \mathrm{KGy}$ had lower phenolic compounds than non-irradiated control in the mint extract. While, irradiated mint at $20 \mathrm{KGy}$ had higher phenolic compounds. The significant decreases in the phenolic contents were 241.61, 249.02 and 251.30 $\mathrm{mg} / 100 \mathrm{~g}$ for samples irradiated at 5, 10 and $15 \mathrm{kGy}$, respectively, compared to the content in case of nonirradiated control $(251.94 \mathrm{mg} / 100 \mathrm{~g})$. While, the increases in the phenolic contents were $258.82 \mathrm{mg} / 100 \mathrm{~g}$ for sample irradiated at $20 \mathrm{kGy}$, compared to the content in case of non-irradiated (control)

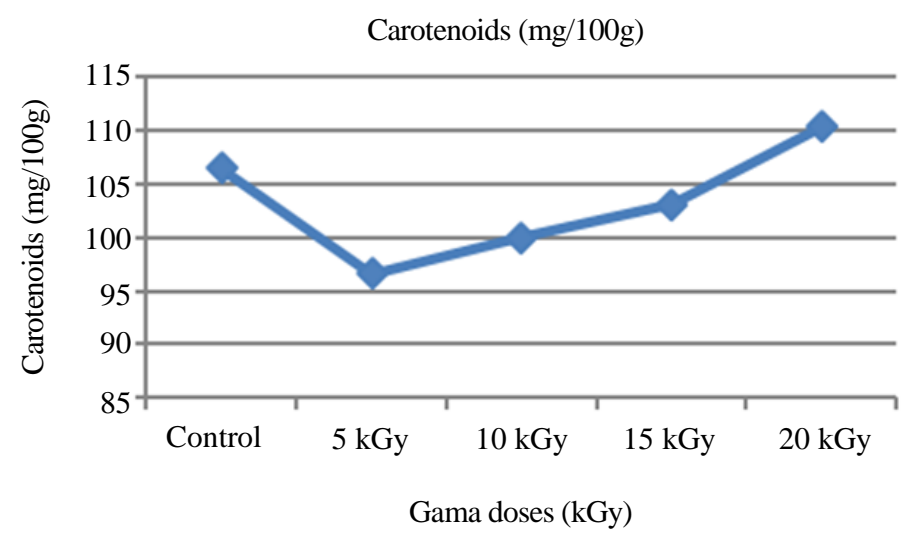

Fig. 5: Effect of gamma radiation doses on carotenoids of peppermint oil

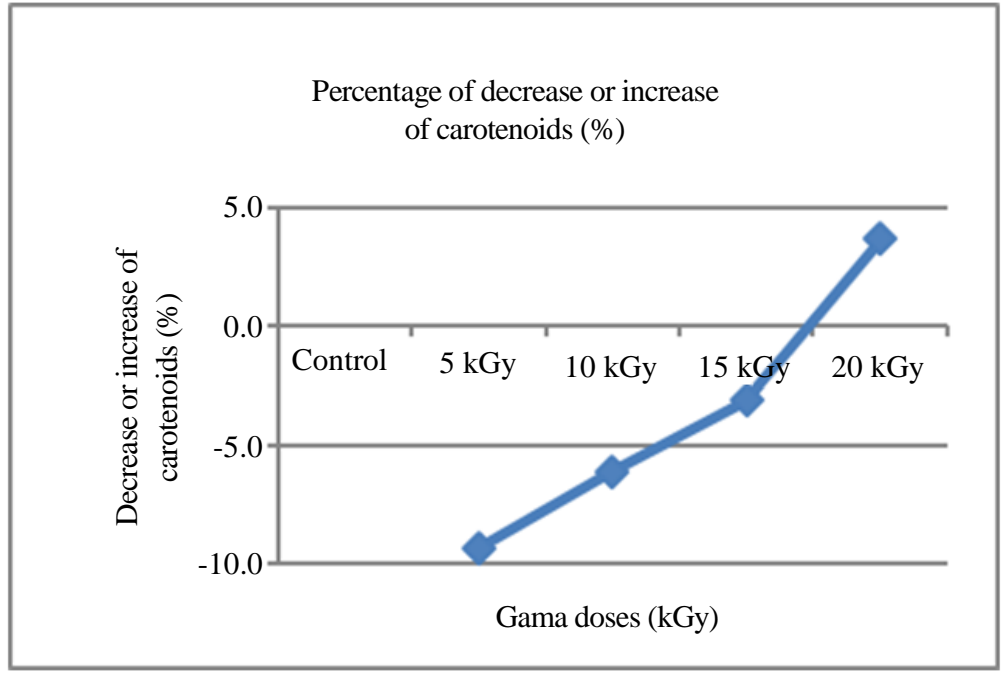

Fig. 6: Decrease or increase of carotenoids of peppermint oil at gamma radiation 


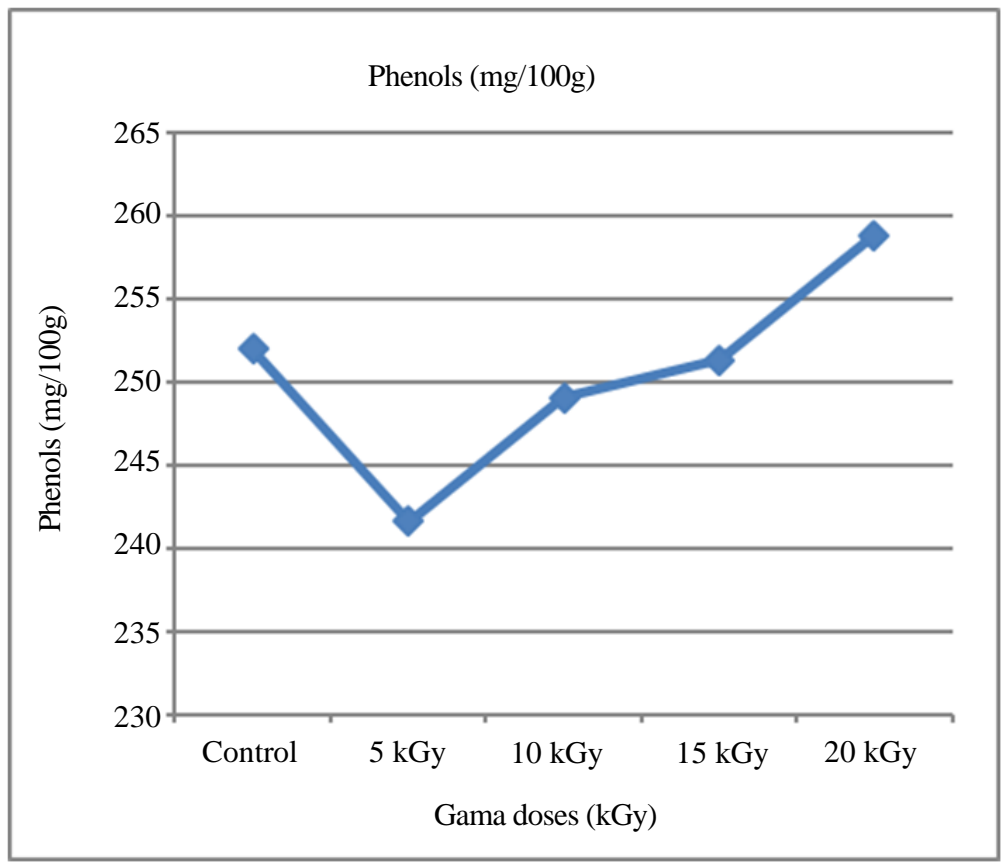

Fig. 7: Effect of gamma radiation doses on phenols of peppermint oil

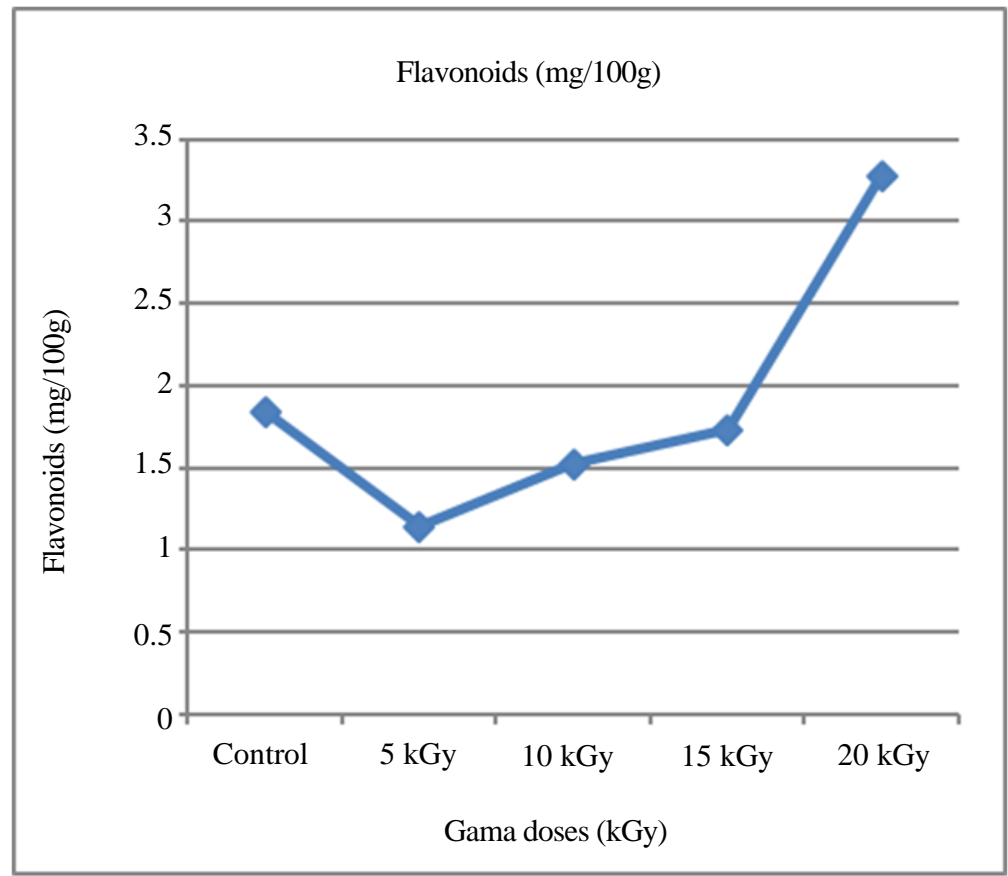

Fig. 8: Effect of gamma radiation doses on flavonoids of peppermint oil

The data demonstrated that the irradiated mint at 5 , 10, $15 \mathrm{KGy}$ had lower flavonoids, compounds than nonirradiated control in the mint extract. While, irradiated mint at $20 \mathrm{KGy}$ had higher flavonoids compounds.

The significant decreases in the flavonoids contents were $1.14,1.52$ and $1.73 \mathrm{mg} / 100 \mathrm{~g}$ for samples irradiated at 5, 10 and $15 \mathrm{kGy}$, respectively, compared to the content in case of non-irradiated control $(1.84 \mathrm{mg} / 100 \mathrm{~g})$. While, the increases in in the phenolic contents were $3.28 \mathrm{mg} / 100 \mathrm{~g}$ for sample irradiated at $20 \mathrm{kGy}$, compared to the content in case of non-irradiated (control). The maximum increase was obtained at $20 \mathrm{kGy}$ dose.

Phenols are found in food either freely or as glycosides. There are more than 8000 kinds of natural 
phenols that are known to be in plants. Phenols exist in food are divided into two main divisions, aromatic phenols and flavonoids (Kim and Lee, 2004).

Percentage of decreasing or increasing of phenolic differed between all the tested mint samples compared with control samples in Fig. 9. For phenolic, it was noticed that negative percentage of $-4.100,-1.159$ and $-0.254 \%$, for irradiated samples of 5, 10 and $15 \mathrm{kGy}$, compared to nonirradiated sample (control), while at the irradiated sample with $20 \mathrm{kGy}$ has positive percentage of $2.731 \%$, compared to non-irradiated sample (control).

Percentage of decreasing or increasing of flavonoids differed between all the tested mint samples compared with control samples in Fig. 10. For flavonoids, it was noticed that negative percentage of $-38.133,-17.511$ and $6.114 \%$, for irradiated samples of 5,10 and $15 \mathrm{kGy}$, compared to non-irradiated sample (control). While, at the irradiated sample with $20 \mathrm{kGy}$ has a positive percentage of $78.003 \%$, compared to non-irradiated sample (control).

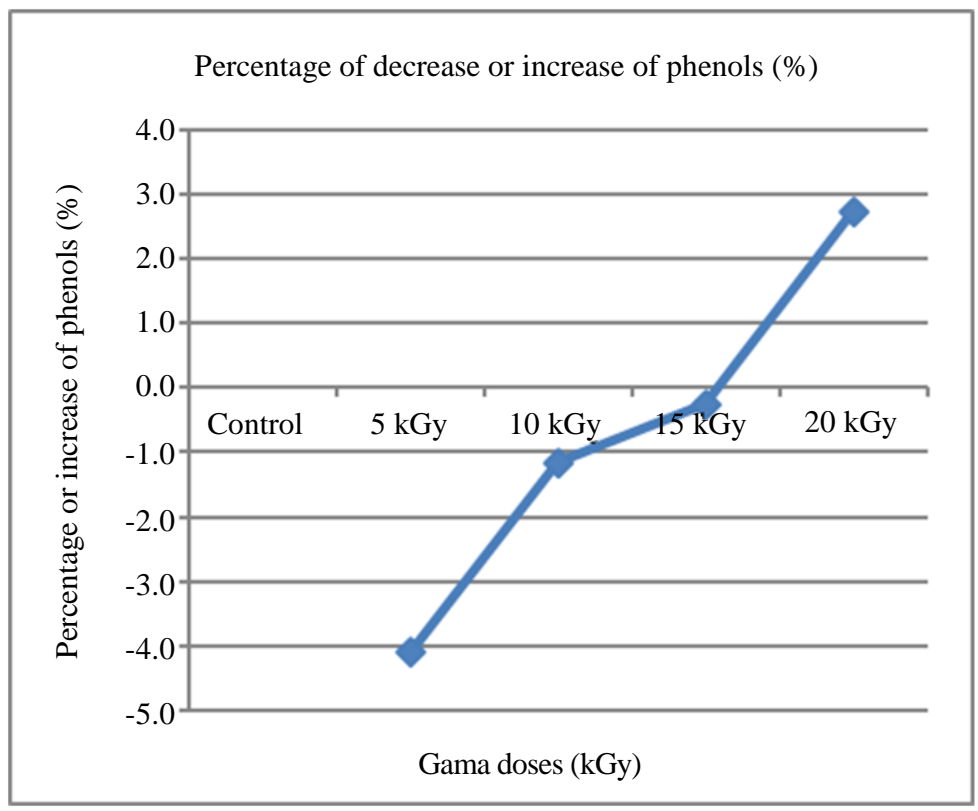

Fig. 9: Percentage of decrease or increase of phenols of peppermint oil at gamma radiation

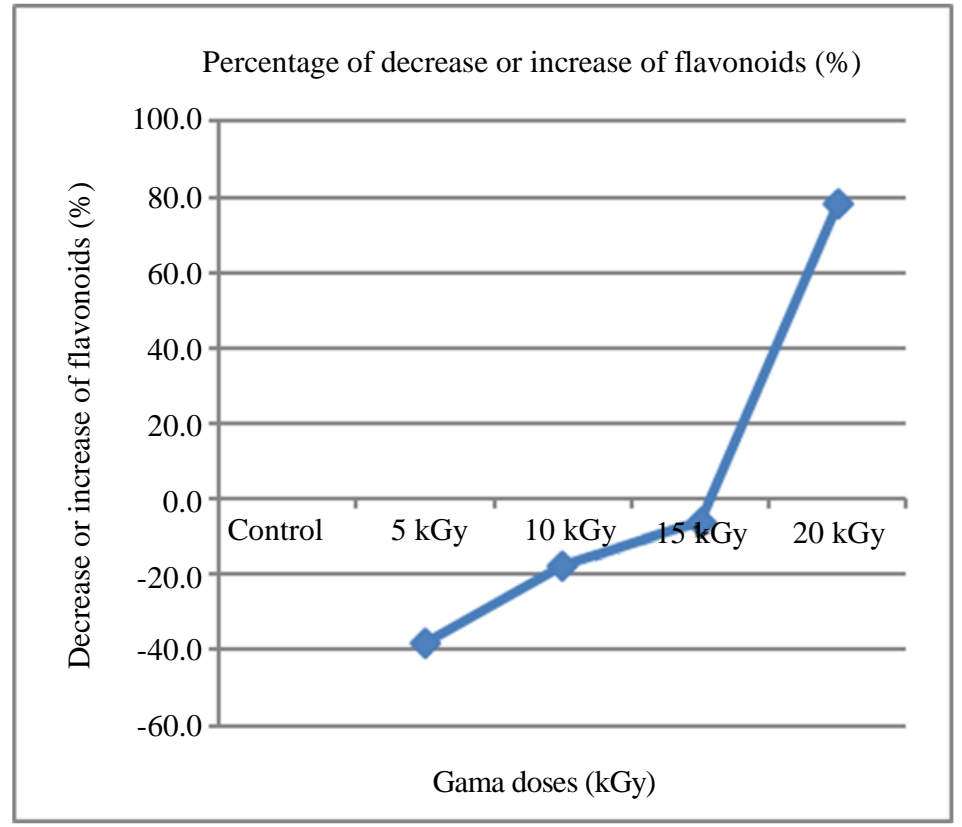

Fig. 10: Percentage of decrease or increase of flavonoids of peppermint oil at gamma radiation 
Flavonoids are vegetable dyes spread in different parts of the plants. They are divided into several various divisions that include Flavones. More precisely, Flavones are considered to be compounds that their color range varies from colorless to light yellow and can be found in citrus, cumin and mint (Alessandro et al., 2003).
The Effects of $\gamma$-Irradiation and the Total Antioxidant and Ascorbic Acid

The effects of $\gamma$-irradiation and the total antioxidant and ascorbic acid are shown in Table 3 and Fig. 11 and 12.

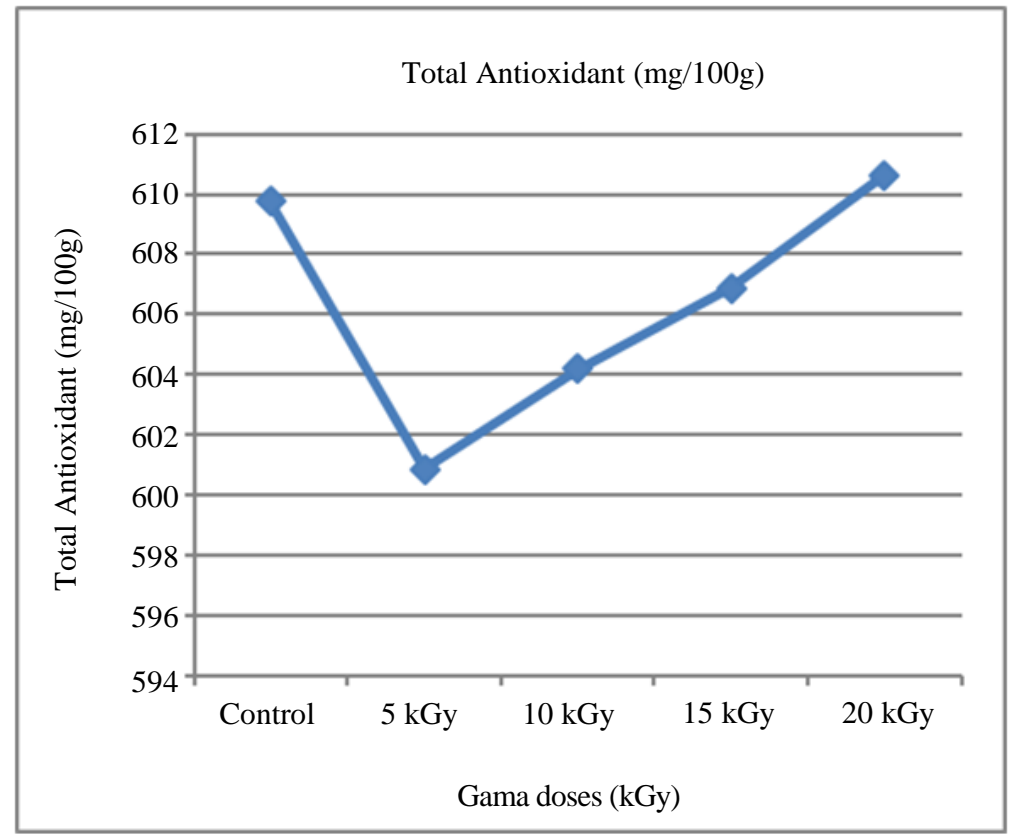

Fig. 11: Effect of gamma radiation doses on Total Antioxidant of Peppermint oil

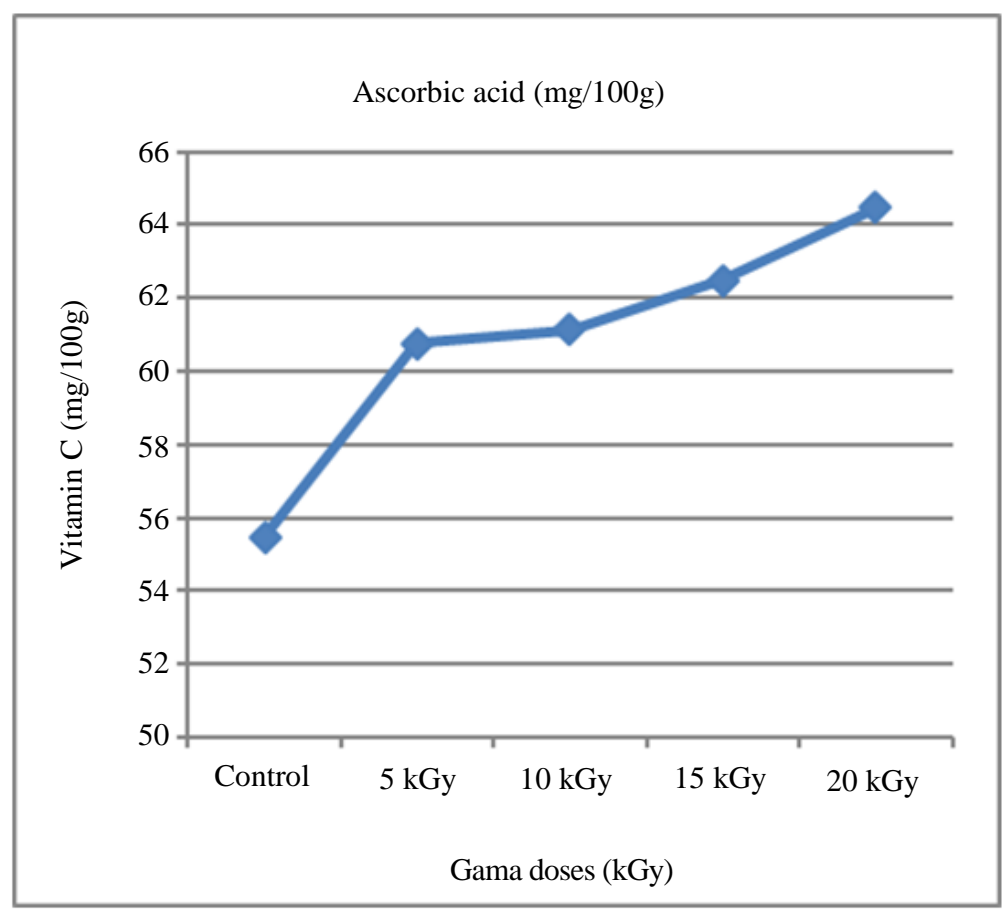

Fig. 12: Effect of gamma radiation doses on Ascorbic acid of Peppermint oil 
The data demonstrated that the irradiated mint at 5, 10, $15 \mathrm{KGy}$ had lower Total Antioxidant compounds than non-irradiated control in the mint extract. While, irradiated mint at $20 \mathrm{KGy}$ had higher total Antioxidant compounds. The significant decreases in the Total Antioxidant contents were 600.87, 604.20 and 606.87 $\mathrm{mg} / 100 \mathrm{~g}$ for samples irradiated at 5, 10 and $15 \mathrm{kGy}$, respectively, compared to the content in case of nonirradiated control $(609.75 \mathrm{mg} / 100 \mathrm{~g})$. While, the increases in the Total Antioxidant contents were $610.62 \mathrm{mg} / 100 \mathrm{~g}$ for sample irradiated at $20 \mathrm{kGy}$, compared to the content in case of non-irradiated (control).

The data demonstrated that the irradiated mint at 5, 10, $15 \mathrm{KGy}$ had lower Ascorbic acid compounds than non-irradiated control in the mint extract. While, irradiated mint at $20 \mathrm{KGy}$ had higher Ascorbic acid compounds. The significant increase in the Ascorbic acid contents were $60.77,61.15,62.48$ and 64.47 $\mathrm{mg} / 100 \mathrm{~g}$ for samples irradiated at 5, 10, 15 and 20 $\mathrm{kGy}$, respectively, compared to the content in case of non-irradiated control $(55.47 \mathrm{mg} / 100 \mathrm{~g})$. So, the lowest value of the Ascorbic acid contents was 55.47 $\mathrm{mg} / 100 \mathrm{~g}$ for sample non-irradiated. While, the highest value of the Ascorbic acid contents was 64.47 $\mathrm{mg} / 100 \mathrm{~g}$ for sample irradiated was obtained at $20 \mathrm{kGy}$ dose. It was obvious that $20 \mathrm{kGy}$ irradiation dose led to the highest increase in the total antioxidant.

The present findings are in good agreement with that of Taipina et al. (2009) who reported that there was no loss of the antioxidant content of pecan nuts as a result of gamma. While Huang and Mau (2006) found that the antioxidant content of the methanolic extract of Agaricusblazei was $45 \mathrm{mg} / 100 \mathrm{~g}$ and this amount was increased to $106 \mathrm{mg} / 100 \mathrm{~g}$ after $20 \mathrm{kGy}$ of $\gamma$-irradiation.

Percentage of decreasing or increasing of total Antioxidants differed between all the tested mint samples compared with control samples in Fig. 13. For total Antioxidants, it was noticed that negative percentage of $-1.456,-0.910$ and $-0.472 \%$ for irradiated samples of 5, 10 and $15 \mathrm{kGy}$, compared to non-irradiated sample (control), while at the irradiated sample with 20 $\mathrm{kGy}$ has a positive percentage of $0.143 \%$, compared to non-irradiated sample (control).

Percentage of decreasing or increasing of Ascorbic acid differed between all the tested mint samples compared with control samples in Fig. 14. For Ascorbic acid, it was noticed that positive percentage of $9.555,10.240,12.637$ and $16.225 \%$ for irradiated samples of 5,10 and $15 \mathrm{kGy}$, compared to nonirradiated sample (control). So, the lowest increase was $9.555 \%$ in the irradiated sample with $5 \mathrm{kGy}$. While, the highest increase was $16.225 \%$ at the irradiated sample with $20 \mathrm{kGy}$.
Intense and/or prolonged thermal treatment may be responsible for a significant loss of natural antioxidants, as most of these compounds are relatively unstable. Yet in some cases, drying process causes little or no change to the content and activity of naturally occurring antioxidants, such as carotenoids and vitamin C (e.g., lycopene) according to Nicoli et al. (1999).

\section{Statical Analysis}

The economic benefit of using gamma irradiation with different radiation levels on the quality characteristics of dried mint oil.

Table 1 showed that the use of irradiation with gamma rays at different radiation levels, which are 5, 10,15 and $20 \mathrm{kGy}$, led to the effect on the quality specifications of oil extracted from dried mint leaves where the results showed that the highest percentage of chlorophyll A, chlorophyll B, the total chlorophyll, carotenoids in dried mint leaves were at a dose of irradiation of $20 \mathrm{kGy}$, as it was found that the highest value of phenolic compounds was at a dose of irradiation of $20 \mathrm{kGy}$.

By performing a variance analysis of the quality characteristics of the oil extracted from dried mint leaves and measured with the content of every $100 \mathrm{~g}$ of oil extracted from chlorophyll A, chlorophyll B, carotene, phenol, flavonoids, antioxidant compounds, ascorbic acid by mass at different irradiation levels 5 , $10,15,20 \mathrm{kGy}$ and it was found from the results shown in Table 3 that there were significant differences in the content of chlorophyll (A), chlorophyll (B), phenol, flavonoids, antioxidants, ascorbic acid, where the calculated value of $F$ was about 459.881, 17606.373, 632.746, 14.806, 88,844 and 4,666, respectively. While there was no significant difference in carotene content as the calculated $\mathrm{F}$ value reached 1.383 .

By conducting LSD test to measure the least significant difference between the control sample and the radiation irradiated samples with gamma rays to know the fundamental differences between the different averages and to know the level of irradiation due to the greater impact on the quality specifications of peppermint oil, it was found from the results shown in Table 4 that the use of irradiation with gamma rays At $20 \mathrm{kGy}$, the most influencing was the higher content of chlorophyll (a) and chlorophyll (b). While the use of the level of irradiation with gamma rays at the level of 15 kGy had a greater impact on the high content of carotene, phenol, flavonoids. Also, the use of irradiation at $10 \mathrm{kGy}$ level had the best effect on the high content of antioxidant and ascorbic acid. 
Abd El-Rahman Abd El-Raouf Ahmed et al. / American Journal of Agricultural and Biological Sciences 2020, Volume 15: 83.97 DOI: 10.3844/ajabssp.2020.83.97

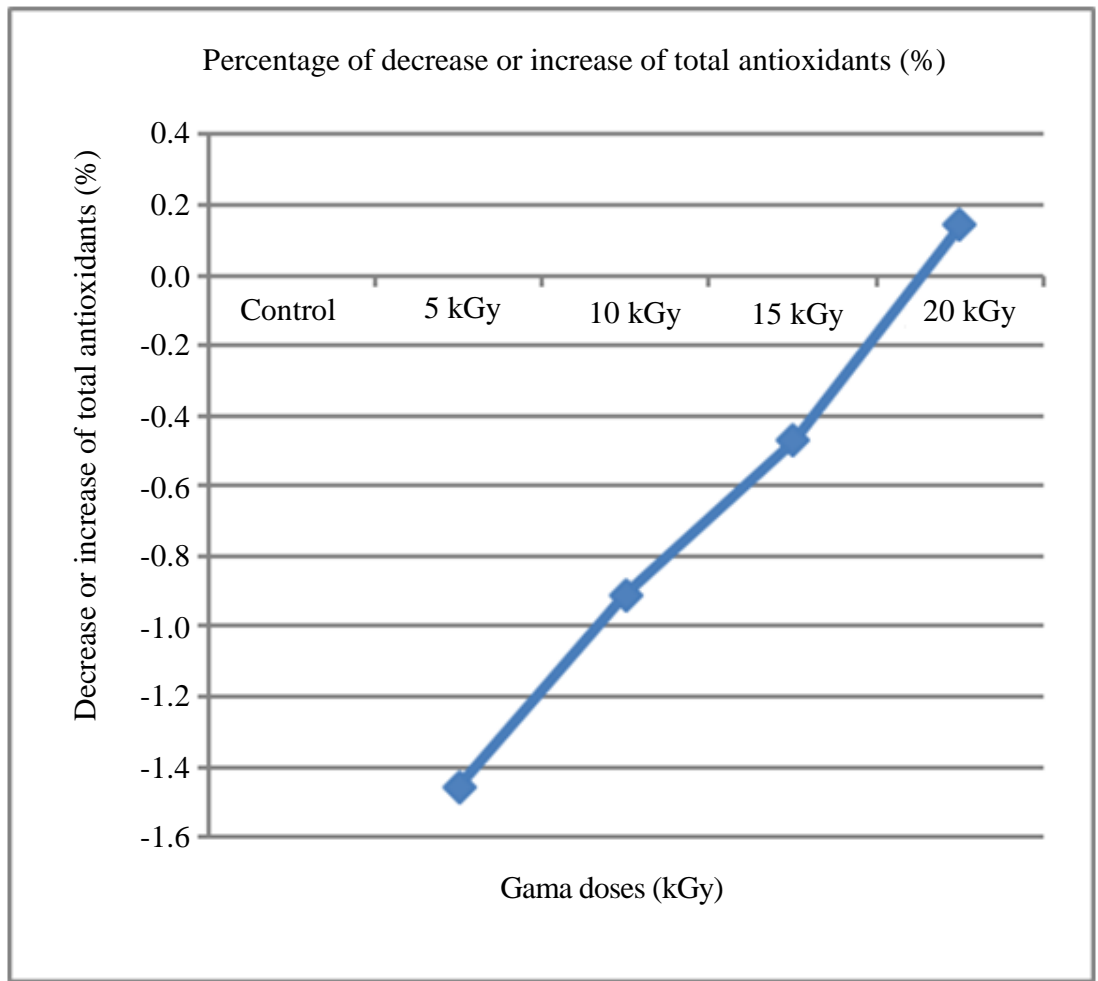

Fig. 13: Percentage of decrease or increase of total antioxidants of peppermint oil at gamma radiation

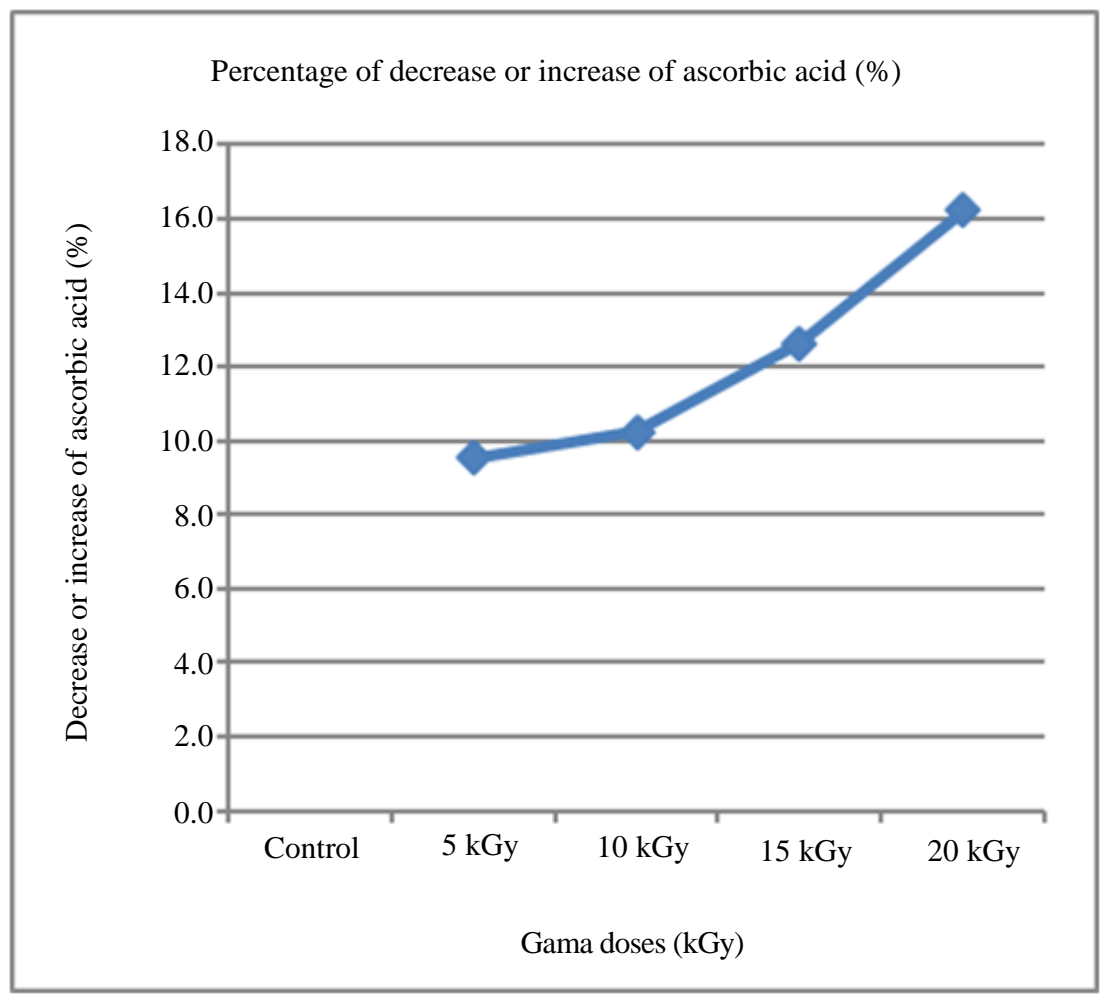

Fig. 14: Percentage of decrease or increase of ascorbic acid of peppermint oil at gamma radiation 
Abd El-Rahman Abd El-Raouf Ahmed et al. / American Journal of Agricultural and Biological Sciences 2020, Volume 15: 83.97 DOI: 10.3844/ajabssp.2020.83.97

Table 3: Analysis of variance of quality characteristics of oil extracted from dried mint leaves at different irradiation doses

\begin{tabular}{|c|c|c|c|c|c|c|}
\hline \multicolumn{2}{|l|}{ Properties of Oil Mint } & Sum of Squares & DF & Mean Square & $\mathrm{F}$ & Sig. \\
\hline \multirow[t]{3}{*}{ Chlorophyll a (mg/100g) } & Between Groups & 34048.254 & 4 & 8512.064 & 459.881 & 0.000 \\
\hline & Within Groups & 185.093 & 10 & 18.509 & & \\
\hline & Total & 34233.347 & 14 & & & \\
\hline \multirow[t]{3}{*}{ Chlorophyll b (mg/100g) } & Between Groups & 109523.987 & 4 & 27380.997 & 17606.373 & 0.000 \\
\hline & Within Groups & 15.552 & 10 & 1.555 & & \\
\hline & Total & 109539.538 & 14 & & & \\
\hline \multirow[t]{3}{*}{ Carotenoids (mg/100g) } & Between Groups & 259.461 & 4 & 64.865 & 1.383 & 0.308 \\
\hline & Within Groups & 469.048 & 10 & 46.905 & & \\
\hline & Total & 728.509 & 14 & & & \\
\hline \multirow[t]{3}{*}{ Phenols (mg/100g) } & Between Groups & 457.267 & 4 & 114.317 & 632.746 & 0.000 \\
\hline & Within Groups & 1.807 & 10 & 0.181 & & \\
\hline & Total & 459.074 & 14 & & & \\
\hline \multirow[t]{3}{*}{ Flavonoids (mg/100g) } & Between Groups & 13.638 & 4 & 3.41 & 14.806 & 0.000 \\
\hline & Within Groups & 2.303 & 10 & 0.23 & & \\
\hline & Total & 15.941 & 14 & & & \\
\hline \multirow[t]{3}{*}{ Total Antioxidant $(\mathrm{mg} / 100 \mathrm{~g})$} & Between Groups & 125.169 & 4 & 31.292 & 88.844 & 0.000 \\
\hline & Within Groups & 3.522 & 10 & 0.352 & & \\
\hline & Total & 128.691 & 14 & & & \\
\hline \multirow[t]{3}{*}{ Ascorbic acid (mg/100g) } & Between Groups & 145.812 & 4 & 36.453 & 4.666 & 0.022 \\
\hline & Within Groups & 78.124 & 10 & 7.812 & & \\
\hline & Total & 223.936 & 14 & & & \\
\hline
\end{tabular}

Source: According to Tables 1 and 2

Table 4: LSD test results

\begin{tabular}{|c|c|c|c|c|}
\hline $\begin{array}{l}\text { Properties of Oil Mint } \\
\text { Chlorophyll a }\end{array}$ & $\begin{array}{l}\text { Control (I) } \\
\text { Zero Gama level }\end{array}$ & $\begin{array}{l}\text { Treatments }(\mathrm{J}) \\
\text { Gama dose }\end{array}$ & Mean Difference (I-J) & Sig. \\
\hline & $0 \%$ & $5 \%$ & 75.651 & 0.000 \\
\hline & & $10 \%$ & 72.315333 & 0.000 \\
\hline & & $15 \%$ & 128.002333 & 0.000 \\
\hline \multirow[t]{4}{*}{ Chlorophyll b } & & $20 \%$ & 7.227333 & 0.067 \\
\hline & $0 \%$ & $5 \%$ & 107.285333 & 0.000 \\
\hline & & $10 \%$ & 95.433 & 0.000 \\
\hline & & $15 \%$ & 120.997333 & 0.000 \\
\hline \multirow[t]{4}{*}{ Carotenoids } & & $20 \%$ & -104.300667 & 0.000 \\
\hline & $0 \%$ & $5 \%$ & 4.375333 & 0.452 \\
\hline & & $10 \%$ & 7.492667 & 0.21 \\
\hline & & $15 \%$ & 11.711333 & 0.063 \\
\hline \multirow[t]{4}{*}{ Phenols } & & $20 \%$ & 9.932833 & 0.106 \\
\hline & $0 \%$ & $5 \%$ & 17.116333 & 0.000 \\
\hline & & $10 \%$ & 7.242 & 0.000 \\
\hline & & $15 \%$ & 6.836 & 0.000 \\
\hline \multirow[t]{4}{*}{ Flavonoids } & & $20 \%$ & 9.9044 & 0.000 \\
\hline & $0 \%$ & $5 \%$ & 0.590667 & 0.163 \\
\hline & & $10 \%$ & -0.296 & 0.467 \\
\hline & & $15 \%$ & -2.224 & 0.000 \\
\hline \multirow[t]{4}{*}{ Total Antioxidant } & & $20 \%$ & -0.139667 & 0.729 \\
\hline & $0 \%$ & $5 \%$ & 8.888667 & 0.000 \\
\hline & & $10 \%$ & 3.263667 & 0.000 \\
\hline & & $15 \%$ & 5.361333 & 0.000 \\
\hline \multirow[t]{5}{*}{ Ascorbic acid } & & $20 \%$ & 4.416667 & 0.000 \\
\hline & $0 \%$ & $5 \%$ & -7.838 & 0.006 \\
\hline & & $10 \%$ & -8.843333 & 0.003 \\
\hline & & $15 \%$ & -6.439333 & 0.018 \\
\hline & & $20 \%$ & -4.585667 & 0.072 \\
\hline
\end{tabular}

Source: According to Tables 1 and 2 


\section{Conclusion}

The highest content of chlorophyll $a$, chlorophyll $b$, total chlorophyll and content of carotenoids in the dried mint leaves were observed in irradiated samples with 20 $\mathrm{kGy}$. While, the highest content was in the irradiated sample with $5 \mathrm{kGy}$.

The irradiated dried mint leaves at 5, 10, $15 \mathrm{KGy}$ had lower phenolic, flavonoids, Total antioxidant and Ascorbic acid compounds than non-irradiated control in the mint extract. While, irradiated mint at $20 \mathrm{KGy}$ had higher phenolic compounds.

It was found significant differences in the content of chlorophyll (A), chlorophyll (B), phenol, flavonoids, antioxidants, ascorbic acid, while there was no significant difference in the carotene content.

By using of irradiation with gamma rays of $20 \mathrm{kGy}$, the most influencing was the higher content of chlorophyll (a) and chlorophyll (b). While the use of the level of irradiation with gamma rays of $15 \mathrm{kGy}$ had a greater impact on the high content of carotene, phenol, flavonoids. Also, the use of irradiation at $10 \mathrm{kGy}$ level had the best effect on the high content of antioxidant and ascorbic acid.

Therefore, the results indicate that the use of irradiation is a suitable method for dried mint leaf preservation,

\section{Acknowledgement}

We gratefully acknowledge the assistance of laboratory teams at Horticultural research Institute and National Irradiation Center, Egyptian Authority of Atomic Energy.

\section{Author's Contributions}

Abd El-Rahman Abd El-Raouf Ahmed: Designed the research plan.

Gamal Kamal Arafa: Participated in experiment.

Helmy El-Sayed Hassan: Participated in experiment.

Hend Nabil Mohamed: Coordinated the data analysis.

\section{Ethics}

This article is original and contains unpublished material. The corresponding author confirms that all of the other authors have read and approved the manuscript and no ethical issues involved.

\section{References}

Alessandro, T., J. Prasian, M. Benton, N. Botting and R. Moore et al., 2003. Polyphenols, inflammatory response and cancer prevention: Chlorination of isoflavonoids by human neutrophils. J. Nutr., 133: 3773-3777. DOI: 10.1093/jn/133.11.3773S
Amnah, M.A.S. and A.N. Al-Kuraieef, 2013. Antioxidant, microbial and sensory evaluation of fresh mint leaves irradiated with various doses of $\gamma$-irradiation nutrition and food sciences department. Princess Norah Bint Abdulrahman University, Riyadh, KSA. Middle East J. Applied Sci., 3: 122-128.

Anonymous, 1990. Official Methods of Analysis. 20th Edn., Association of Official Analytical Chemists, Washington D.C.

ASEAS, 2018. Ministry of Agriculture. Agricultural Statistics Economic Affairs Sector Agric. Res. Center. Holicultural Res. Institute, Egypt.

Barros, L., E. Pereira, R.C. Calhelha, M. Duenas and A.M. Carvalho et al., 2013. Bioactivity and chemical characterization in hydrophilic and lipophilic compounds of Chenopolium ambrosioides L. J. Funct. Foods, 5: 1732-1740. DOI: 10.1016/j.jff.2013.07.019

Bekhradi, F., M.C. Luna, M. Delshad, M.J. Jordan and J.A. Sotomayor et al., 2015. Effect of deficit irrigation on the postharvest quality of different genotypes of basil including purple and green Iranian cultivars and a Genovese variety. Postharvest Biol. Technol., 100: 127-135. DOI: 10.1016/j.postharvbio.2014.09.017

Crivelli, G., R.C. Nani and L.F. Di Cesare, 2002. Influence of processing on the quality of dried herbs. Giornatescientifiche SOI, 2: 463-464.

Eliana, P., A.I. Pimenta, R.C. Calhelha, A.L. Antonio and S.C. Verde et al., 2016. Effects of gamma irradiation on cytotoxicity and phenolic compounds of Thymus vulgaris L. Mentha x Piperita L. LWT Food Sci. Technol., 71: 370-377. DOI: $10.1016 /$ j.lwt.2016.04.004

Eric, D.B., 2013. Effect of drying methods on nutrient quality of Basil (Ocimum viride) leaves cultivated in Ghana. Department Chem. Eng. Kumasi Polytechnic, Kumasi, Ghana Int. Food Res. J., 20: 1569-1573.

Fatemi, F., A. Allameh, H. Khalafi and J. Ashrafihelan, 2010. Hepatoprotective effects of $\gamma$-irradiated caraway essential oils in experimental sepsis. Applic. Radiat Isotopes, 68: 280-285. DOI: $10.1016 /$ j.apradiso.2009.10.052

Gavahian, M., R. Farhoosh, A. Farahnaky, K. Javidnia and F. Shahidi, 2015. Comparison of extraction parameters and extracted essential oils from Mentha piperita L. using hydro distillation and steam distillation. Int. Food Res. J., 22: 283-288.

Ghanooni, S.H., A. Dadkhah, F. Fatemi and M.R. Zolfaghari1, 2015. Evaluation of $\gamma$-irradiation treatment on the antibacterial activities of Mentha piperita L. essential oils in vitro and in vivo systems (CLP inflammatory model). 
Haruvy, Y. and L. Deschenes, 2003. Packaging quality assurance guidance manual model for safe, shelf stable, ready-to-eat food through high-dose irradiation. Proceedings of the Final Research Coordination Meeting, Montreal, Radiation Processing for Safe, Shelf-Stable and Ready to Eat Food, Jul. 10-14, Vienna, Austria, pp: 238-257.

Huang, S.J. and J.L. Mau, 2006. Antioxidant properties of methanolic extracts from Agaricus blazei with various doses of $\gamma$-irradiation. LWT-Food Sci. Technol., 39: 707-716.

DOI: $10.1016 /$ j.lwt.2005.06.001

Kim, D. and C. Lee, 2004. Comprehensive study on Vitamin C Equivalent Antioxidant Capacity (VCEAC) of various polyphenolics in scavenging a free radical and it structural relationship. Crit. Rev. Food Sci. Nutr., 44: 253-273.

DOI: 10.1080/10408690490464960

Lisiewska, Z., W. Kmiecik and J. Słupski, 2004. Contents of chlorophylls and carotenoids in frozen dill: Effect of usable part and pre-treatment on the content of chlorophylls and carotenoids in frozen dill (Anethumgraveolens L.), depending on the time and temperature of storage. Food Chem., 84: 511-518. DOI: 10.1016/S0308-8146(03)00265-6

Loranty, A., E. Rembiałkowska, E.S. Rosa and R.N. Bennett, 2010. Identification, quantification and availability of carotenoids and chlorophylls in fruit, herb and medicinal teas. J. Food Comp. Anal., 23: 432-441. DOI: 10.1016/j.jfca.2010.01.007

Marinova, D., F. Ribarova and M. Atanassova, 2005. Total phenolics and total flavonoids in Bulgarian fruits and vegetables. J. Univ. Chem. Technol. Metall., 40: 255-260.

Meda, A., C. Lamin, M. Romito, J. Millogo and O. Nacoululma, 2005. Determination of the total phenolic, flavonoid and praline contents in Burkina Fasan Honey, as well as their radical scavenging activity. Food Chem., 91: 571-577. DOI: 10.1016/j.foodchem.2004.10.006

Mizani, M., N. Sheikh, S.N. Ebrahimi, A. Gerami and F.A. Tavakoli, 2009. Effect of gamma irradiation on physico-mechanical properties of spice packaging films. Radiat. Phys. Chem., 78: 806-809.

DOI: 10.1016/j.radphyschem.2009.04.021

Nicoli, M.C., M. Anese and M. Parpinel, 1999. Influence of processing on the antioxidant properties of fruits and vegetables. Trends Food Sci. Technol., 10: 94-100. DOI: 10.1016/S0924-2244(99)00023-0

Oboh, G., 2005. Effect of blanching on the antioxidant property of some tropical green leafy vegeta., LWTFood Sci. Technol., 38: 513-517. DOI: 10.1016/j.lwt.2004.07.007

Oboh, G., A.A. Akindahunsi and A.O. Ademiluyi, 2009. Changes in polyphenols distribution and antioxidant activity during fermentation of some underutilized legumes. Food Sci. Technol. Int., 15: 41-46.

DOI: $10.1177 / 1082013208101022$

Pellegrini, N., M. Serafini, B. Colombia, D. Rio and S. Salvatore et al., 2003. Total antioxidant capacity of plant foods, beverages and oils consumed in Italy assessed by three different in vitro assays. J. Nutr., 133: 2812-2819. DOI: 10.1093/jn/133.9.2812

Schoefs, B., 2002. Chlorophyll and carotenoid analysis in food products. Properties of the pigments and methods of analysis. Trends Food Sci. Technol., 13: 361-371. DOI: 10.1016/S0924-2244(02)00182-6

Shurong, L., G. Meixu and W. Chuanyao, 2005. Use of irradiation to ensure hygienic quality of fresh precut and blanched vegetables and to fu. J. IAEA.TECDO, 1530: 87-105.

Sumanta, N., C.I. Haque, J. Nishika and R. Suprakas 2014. Spectrophotometric analysis of chlorophylls and carotenoids from commonly grown fern species by using various extracting solvents. Res. J. Chem. Sci., 4: 63-69. DOI: 10.1055/s-0033-1340072

Taipina, M.S., L.A. Lamardo, M.B. Rodas and N. DelMastro, 2009. The effects of gamma irradiation on the vitamin E content and sensory qualities of pecan nuts (Carya illinoensis). Radiat. Phys. Chem., 78: 611-613. DOI: 10.1016/j.radphyschem.2009.03.019

Toor, R.K. and G.P. Savage, 2004. Effect of semi-drying on the antioxidant components of tomatoes. Food Chem., 94: 90-97.

DOI: $10.1016 /$ j.foodchem.2004.10.054

UNMS, 2018. Sources: ITC calculations based on UN MTRADE Statistics.

Yousif, A.N., C.H. Scaman, T.D. Durance and B. Girard, 1999. Flavor volatiles and physical properties of vacuum-microwave- and air-dried sweet basil (Ocimum basilicum L.). J. Agric. Food Chem., 47: 4777-4781. DOI: 10.1021/jf990484m

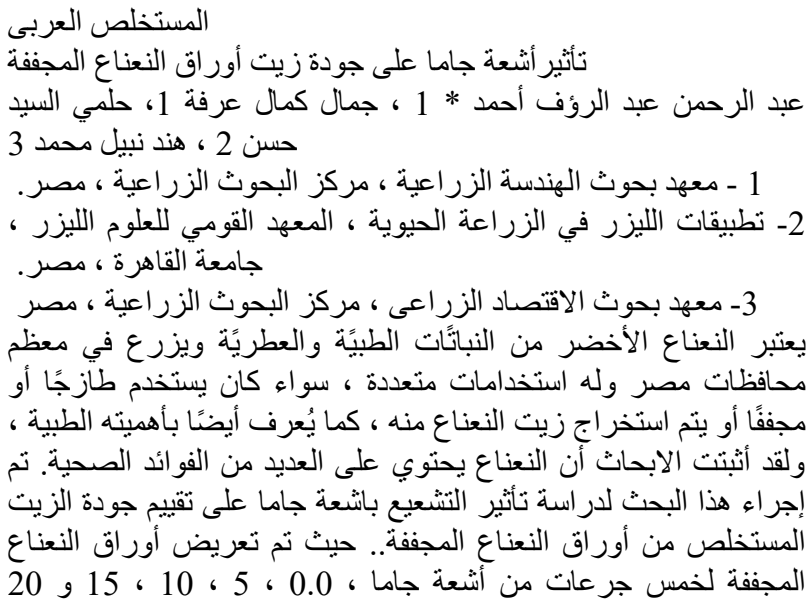


كيلوجراى. وقد تم الكثف عن خصائص اللون مثل الكلوروفيل (أ) ، وكأل

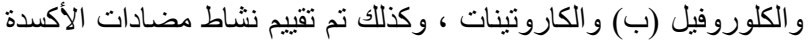

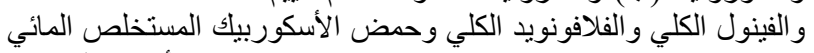

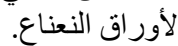

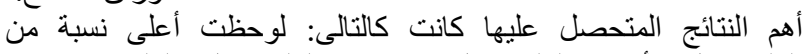

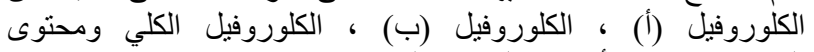

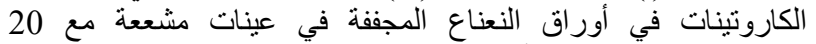

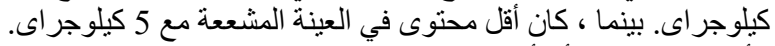

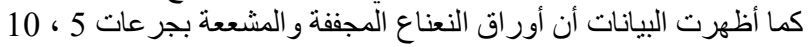

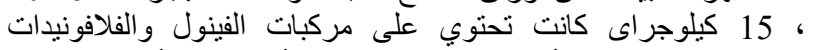

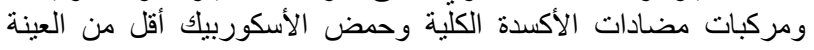

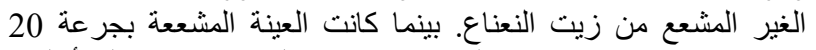
كيلوجر باى تحتوي على مركبات فينولية أعلى أعلى.

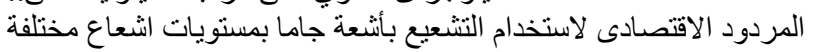

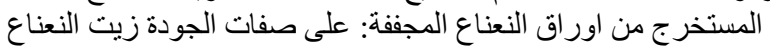

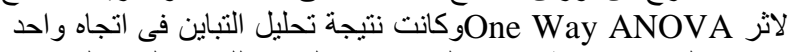
استخدام التثعيع باشعة جاما على صفات الجودة للزيت التئ المستخلص من التهاه

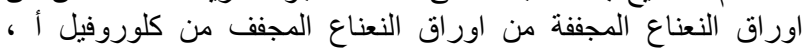
كلوروفيل ب ، الكاروتين ، الفينول ، الفلافونويدز ، مركبات مضادات الفيل

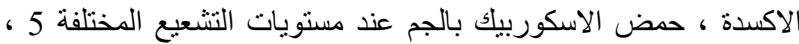

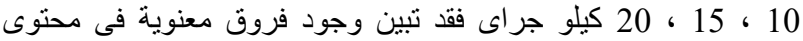

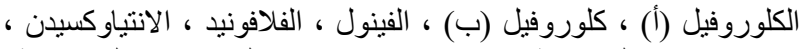

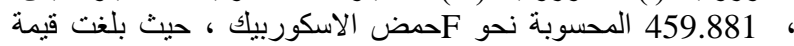

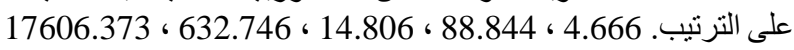
Fينما لا يوجد فروق معنوية فى محتوى الكاروتين حيث بلغت قيمة 1.383.

لقياس اقل فرق معنوى بين عبنة الكنترول و العينات LSD باجر أجناء اختبار

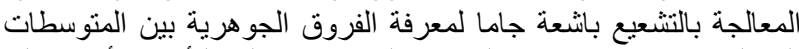

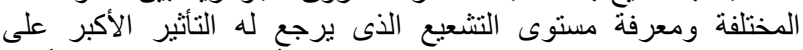

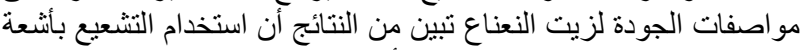

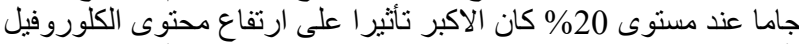

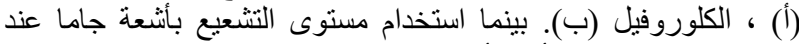
، مستوى 15\% كان له تأثيرا أكبر على ارتفاع محتوى الكاروتين ، الفينول

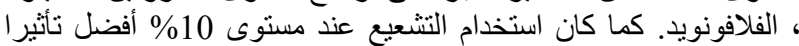

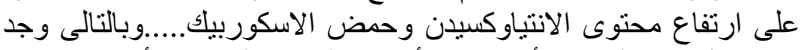

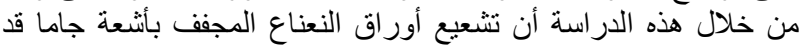
يؤدي إلى تحسين جودة الزيت. 